School of Finance

University of St.Gallen

«QUANTITATIVE EASING AND THE SAFE ASSET ILLUSION»

AleXander BeCHTEL

JENS EISENSCHMIDT

ANGELO RANALDo

Alexia Ventula Veghazy

Working Papers on Finance No. 2021/10

SWISS INSTITUTE OF BANKING AND FINANCE (S/BF - HSG)

JUNE 9, 2021 


\title{
Quantitative Easing and the Safe Asset
}

\section{Illusion*}

\author{
Alexander Bechtel ${ }^{\dagger}$ University of St. Gallen \\ Jens Eisenschmidt ${ }^{\ddagger}$ European Central Bank \\ Angelo Ranaldo ${ }^{\S}$ University of St. Gallen \\ Alexia Ventula Veghazy European Central Bank
}

June 9, 2021

\footnotetext{
*We thank Arvind Krishnamurthy, Giuseppe Maraffino, Hee Su Roh, Jean-David Sigaux, and the participants of the 14th Federal Reserve Bank of New York / New York University, Stern School of Business Conference on Financial Intermediation 2019, 6th International Conference on Sovereign Bond Markets 2019, and of research seminars at the Bank for International Settlements, European Central Bank, Stanford University (reading group), and University of St. Gallen. We also thank Maria Elena Filippin and Gabriela Silova for providing outstanding research assistance.

†E-mail: alexander . bechtel@unisg.ch.

${ }^{\ddagger}$ E-mail: jens.eisenschmidt@ecb.int.

$\S$ E-mail: angelo.ranaldo@unisg.ch.

`E-mail: alexia.ventula_veghazy@ecb.europa.eu.
} 


\title{
Quantitative Easing and the Safe Asset Illusion
}

June 9, 2021

\begin{abstract}
The massive recourse to quantitative easing (QE) calls for a better understanding of its effects on safe assets. Based on a simple balance sheet framework, we show how QE impacts the total amount, cross-sectional distribution, and composition of safe assets in the economy. Analyzing the ECB's Public Sector Purchase Programme (PSPP), we find that the amount of universally accessible safe assets decreases and there is a transfer of safe assets from the non-bank to the banking sector. We call this phenomenon the safe asset illusion. The sectoral shift in the holding structure of safe assets has important implications for financial stability and the cost of secured liquidity.
\end{abstract}

KEYwords: Safe assets, quantitative easing, Public Sector Purchase Programme,secured deposits, repurchase agreements JEL Codes: G12, G18, G21, E43, E52, D40 


\section{Introduction}

Do large-scale asset purchases by central banks - commonly known as Quantitative Easing (QE) — affect the allocation and composition of safe assets in the economy? If so, why and what are the consequences? These are important questions given the enormous and prolonged use of such polices by many central banks around the world. Furthermore, safe assets play an important role for the global financial system and they have been in increasing demand since the financial crisis. (e.g., International Monetary Fund, 2012; Caballero, Farhi, and Gourinchas, 2017; Gorton, 2017).

In this paper, we examine the effect of QE on the total amount, sectoral holdings, and composition of safe assets. We show that even though QE is effectively an exchange of two forms of safe assets - government bonds and central bank reservesit is not neutral to safe assets, creating a "safe asset illusion". The main friction behind this illusion is the exclusive access to central bank reserves by banks, which creates a class of safe assets that is not universally accessible. We start our analysis by deriving conditions for the neutrality of QE in a simple balance sheet framework. Using unique and granular data from the European Central Bank's (ECB) Public Sector Purchase Programme (PSPP), we show that these conditions are violated: The PSPP (1) increases the total amount of safe assets, (2) induces a net-transfer of safe assets from the non-bank to the banking sector, and (3) decreases the amount of universally accessible safe assets. Additionally, we show that the safe asset illusion has distributional consequences for the non-bank sector because non-banks have to pay a safety premium for securely storing their liquidity. Finally, the safe asset illusion also has implications for financial stability because it leads to a deterioration of the collateral quality in money markets creating financial fragility. 
What are safe assets? Safe assets are debt contracts that have money-like attributes, which make them attractive as collateral and a store of value (Nagel, 2016). They are information-insensitive in the sense that there is no need for agents to seek information relevant to the instrument's safety (Dang, Gorton, and Holmström, 2015). Due to these attributes, safe assets usually carry a convenience premium (e.g., Krishnamurthy and Vissing-Jorgensen, 2012). Examples of safe assets are highly rated government bonds or central bank reserves. The key characteristic analyzed in this paper is whether a safe asset is universally accessible. Some safe assets are only accessible to certain economic agents and financial institutions. For instance, while a government bond is accessible to everyone, many institutional frameworks grant access to central bank reserves (hereafter, reserves) to banks only. Therefore, we define reserves as being not universally accessible. Additionally, we distinguish safe assets from so-called quasi-safe assets. Quasi-safe assets behave similarly to safe assets in almost all states of the world. Under these circumstances they provide safety and liquidity benefits and also carry a convenience premium. In bad states of the world, however, quasi-safe assets become information-sensitive as investors begin having doubts about the true value of these assets (e.g., Moreira and Savov, 2017; Kacperczyk, Perignon, and Vuillemey, 2018). Thus, their convenience yield is wobbling in the sense that their safety and liquidity attributes decrease or disappear (Gorton, 2017). Examples of quasi-safe assets are private debt securities such as certificates of deposits (CDs), bank deposits, mortgage-backed securities (e.g., He and Song, 2020) or public debt securities issued by sovereigns with worse credit ratings.

The contribution of this paper is to examine the effects of QE on safe assets as well as the implications for financial stability and the distribution of wealth in the 
economy. To this end, we formalize the safe asset illusion in a simple balance sheet framework that enables us to analyze the interactions between the central bank, the non-bank sector, and the banking sector from a safe asset perspective. Based on this framework, we derive conditions for the neutrality of QE to safe assets. In particular, we show that (1) QE is neutral to the total amount of safe assets if the central bank purchases only safe assets (for instance, only safe government bonds), (2) it is neutral to the sectoral holdings of safe assets if the central bank purchases only safe government bonds and only from banks, and (3) it is never neutral to the composition of safe assets, that is, to the share of universally accessible safe assets.

In our empirical analysis, we bring the balance sheet framework to data from the ECB in order to test if the neutrality conditions are violated and to what extent they are violated. To this end, we analyze two unique and granular data sets: first, data on PSPP purchases conducted by the ECB between March 2015 and December 2018. ${ }^{1}$ Second, we analyze the ECB's Securities Holdings Statistics (SHSS), which contains security-level portfolio holdings of investors resident in the euro area. SHSS data covers the main categories of assets (government and corporate bonds, asset-backed securities and covered bonds) and investors (banks, households, insurance companies and pension funds, other non-financials, and foreign investors).

We find that between Q1 2015 and Q4 2018, the total amount of safe assets in the euro area (EA) increases from $49 \%$ to $55 \%$ of euro area GDP. Additionally, there is a transfer of safe assets from the non-bank to the banking sector. While the banking sector increases its safe asset holdings as a share of euro area GDP by

\footnotetext{
${ }^{1}$ To be precise, the PSPP is implemented by the Eurosystem. We use the terms ECB and Eurosystem interchangeably.
} 
more than $10.9 \%$, non-banks even reduce their holdings by $4.4 \%$. We also document significant cross-sectional variation in the preference of non-banks to hold safe assets, which leads to cross-sectional differences in how non-banks rebalance their safe asset holdings. The foreign sector is the biggest seller of these assets. Insurance companies and pension funds, on the other hand, even increase their safe asset holdings. Finally, the share of universally accessible safe assets decreases from $46 \%$ of euro area GDP in Q1 2015 to 39\% in Q4 2018. Our findings are in line with Koijen et al. (2020), who examine portfolio rebalancing behavior of different sectors during the PSPP until the end of 2017. They look broadly at various asset classes including corporate debt, asset-backed securities, and equity. In contrast, we focus on public debt adding reserves into the mix. In our analysis, we distinguish between safe and quasi-safe assets allowing us to make statements about the effect of QE on the (cross-sectional) distribution and composition of safe assets.

We study two major implications of the safe asset illusion. First, we analyze the impact of the safe asset illusion on the cost of safely storing liquidity. There are two main ways to safely store liquidity: reserves and general collateral (GC) repurchase agreements (repos). While banks can access both, non-banks can only access the latter. As a consequence of the safe asset illusion, non-banks are forced to pay a premium compared to banks if they want to safely store their liquidity. This safe storage premium arising from the segmentation in the market of reserves amounts to $7-10$ basis points on average. For non-banks, this is a substantial additional cost considering the level of short-term rates. If banks had to pay this premium, their storage cost would have been EUR $3.3-4.7$ billion higher between March 2015 and December 2018. Second, we examine the implications of the safe asset illusion for financial stability. To this end, we study the role of universally accessible 
safe assets as collateral. Through its large-scale government bond purchases, the ECB reduces the share of outstanding universally accessible safe assets triggering a substitution in collateralization of safe assets with quasi-safe assets. Consequently, the overall collateral quality in money markets decreases, which leads to financial fragility (Gorton and Ordonez, 2014) or fragile liquidity (Moreira and Savov, 2017).

The safe asset illusion contrasts with the irrelevance paradigm of Wallace (1981), which stipulates that (non-standard) open market operations in assets are irrelevant and do not have any real effect. Woodford (2012) makes use of this paradigm pointing to the fact that targeted asset purchases would not have any effect on prices in a representative agent asset pricing model. ${ }^{2}$ There are three strands of the literature that aim to refute these results pointing to channels through which QE might still affect prices: First, according to the signaling channel the accommodative effects of QE originate from the central bank's credible signal to keep rates low for longer periods. QE might influence market participants' views about future monetary policy decisions and the state of the economy. Second, the portfolio rebalancing channel hinges on the imperfect substitutability of assets because they bear specific risk premiums or provide some utility such as liquidity or collateral services (Gertler and Kiyotaki, 2010; Cúrdia and Woodford, 2011). Also, according to preferred-habitat theories investors have a preference for a particular asset or segment of the yield curve (Modigliani, Franco; Sutch, 1966). By altering the amount of assets held in agents' portfolios, QE can then affect asset prices even in the presence of arbitrageurs (Vayanos and Vila, 2021).

\footnotetext{
${ }^{2}$ More specifically, in these models QE is neutral because it involves an exchange of government bonds for reserves leading only to a reshuffle of government assets held by economic agents. These agents ultimately suffer from losses of the central bank because losses lead to higher taxes; hence, it makes no difference whether households hold the bonds directly or via the central bank.
} 
Our paper contributes to the third and most recent channel of QE non-neutrality: the reserve channel. This channel centers around the segmentation in the market of central bank reserves. It highlights one key distinguishing characteristic between the purchased government bonds and newly created reserves: Even though both are public liabilities, reserves are issued by central banks and only held by banks; they are not universally accessible. Another important difference is that interest on reserves is a policy variable while interest on bonds is a market variable (Reis, 2017). When central banks buy safe government bonds from banks, QE is neutral from a safe asset perspective as it swaps two safe assets. However, when central banks buy government bonds from non-banks, QE has an unequal impact as non-banks receive the proceeds from selling government bonds in the form of bank deposits exposing them to credit risk in the banking sector. For the non-bank sector, QE is equivalent to a swap of safe assets (government bonds) for quasi-safe assets (bank deposits). Prior research has studied non-neutrality and the effects on inflation (e.g., Benigno and Nisticò, 2017). Christensen and Krogstrup (2019) analyze the portfolio rebalancing effects on banks and non-banks focusing on the reduction of asset portfolio duration. We show that QE induces a redistribution of safe assets from non-banks to banks due to different degrees of accessibility to safe assets. Additionally, we point to the distributional consequences that arise due to a safe storage premium for non-banks. Finally, we show that the safe asset illusion leads to financial fragility by reducing the collateral quality in short-term funding markets.

Our paper contributes to two additional strands of the literature: First, research on safe assets shows that their scarcity leads to global demand and supply imbalances with effects for financial stability and the real economy (e.g, Caballero, Farhi, and 
Gourinchas, 2008; Caballero and Krishnamurthy, 2009; Barro et al., 2017). It also distinguishes between public/safe and private/quasi-safe assets showing that private safe assets cease to be safe during crises (Sunderam, 2015; Moreira and Savov, 2017; Kacperczyk, Perignon, and Vuillemey, 2018) or that public safe assets crowd out private ones (Azzimonti and Yared, 2018). Our contribution is to show that QE can exacerbate the safe asset scarcity for the non-bank sector as it induces a transfer of these assets from non-banks to banks. In contrast to the existing literature that focuses on the United States, our work analyzes and quantifies safe and quasi-safe assets in the euro area. Additionally, we show that there is significant heterogeneity in the preference to hold safe assets across different sectors of the economy.

Second, we contribute to the debate about monetary policy as tool for financial stability (e.g., Stein, 2012; Gorton and Ordonez, 2014; Greenwood, Hanson, and Stein, 2016; Moreira and Savov, 2017). As banks issue too many quasi-safe assets (short-term debt) compared to the socially optimal level, Stein (2012) argues that central banks can use their reserves as a tool to mitigate this problem. In the same line of reasoning, Greenwood, Hanson, and Stein (2016) advocate for a more active use of the Federal Reserves's balance sheet to reduce financial risk arising from excessive amounts of maturity transformation. Our results suggest that providing the banking sector with additional liquidity through government bond purchases indeed strengthens the financial stability of banks. However, we also show that this comes at the cost of a reduction of universally accessible safe assets leading to higher general financial fragility (Gorton and Ordonez, 2014) or fragile liquidity (Moreira and Savov, 2017).

The remaining paper is structured as follows: In Section 2, we introduce the concept of safe and quasi-safe assets and present the safe asset illusion in a simple 
balance sheet framework. In Section 3, we test the predictions from the balance sheet framework using securities holdings data from the ECB. Section 4 examines the distributional consequences of the safe asset illusion for the banking and nonbank sector as well as the implications for financial stability. Finally, in Section 5, we discuss the policy implications of our findings and conclude.

\section{The safe asset illusion}

\subsection{Safe and quasi-safe assets}

Safe assets are usually debt contracts that have money-like attributes, which make them attractive as a store of value, tool for liquidity management, and collateral (e.g., Nagel, 2016; Caballero, Farhi, and Gourinchas, 2017; Caballero and Farhi, 2018). Due to these attributes, safe assets usually carry a convenience yield (e.g., Krishnamurthy and Vissing-Jorgensen, 2012; Gorton, 2017). Classical examples are government bonds, such as Treasury bills or Bunds. Safe assets enable economic agents to transact without being exposed to adverse selection. It is inefficient to produce private information about these assets. Therefore, there is no danger that the counterparty has an information advantage, which would create a lemons problem (e.g., Gorton and Pennacchi, 1990; Gorton, 2017). Dang, Gorton, and Holmström (2015) call this characteristic "information sensitivity".

We follow the extant literature and distinguish between safe and quasi-safe assets. Both are information-insensitive during normal times. Safe assets are less prone to information events than quasi-safe assets because they are not or less exposed to bad news. Additionally, since safe assets are issued by public entities, they are backed 
by taxation, which makes them inherently more stable and safe (Krishnamurthy and Vissing-Jorgensen, 2015). Therefore, safe assets tend to remain informationinsensitive even in times of uncertainty. Quasi-safe assets on the other hand are more prone to becoming information-sensitive. Intuitively speaking, because of the new information, the holders of quasi-safe assets become suspicious about the fundamental value of the underlying debt. They start producing information as soon as the value of information exceeds the cost of producing it. Moreira and Savov (2017) call this situation "fragile liquidity". Fragile liquidity is as good as any other liquidity during quiet times, but it evaporates during times of uncertainty. Gorton and Ordonez (2014) describe the same phenomenon using the term "financial fragility". They show how a small shock to the confidence in safe debt can have large consequences for financial stability at the end of a credit boom. Zou (2019) presents a model in which liquid markets are prone to a self-fulfilling market freeze when buyers suddenly start producing information. This triggers a transition from a liquid to an illiquid state from which there is no equilibrium path back without exogenous intervention. Finally, Kacperczyk, Perignon, and Vuillemey (2018) show that private safe assets cease to be perceived as safe in times of stress. They lose their safety premium.

In this paper, we add one additional dimension to the safe asset taxonomy. We divide (quasi-)safe assets into those that are universally accessible and those that are not. Table 1 summarizes our taxonomy. Differences in the accessibility of safe assets are the main driver behind the safe asset illusion. The classical example for a universally accessible safe asset are government bonds, such as U.S. Treasuries or German Bunds. Reserves on the other hand are safe, but they are not universally accessible. Examples for universally accessible quasi-safe assets 
are, among others, government bonds with a low credit rating, mortgage-backed securities, or corporate bonds. Consequently, safe assets are always issued by the public sector, but not all public debt is safe. Finally, quasi-safe assets that are not universally accessible might include investment vehicles such as closed-end funds with a very good credit rating. In this paper, we focus on safe assets, that is, on the first column of Table 1. In Section 3, we operationalize our defintion of safe assets and outline which assets fall into which category.

Table 1: Safe and quasi-safe assets

\begin{tabular}{lll}
\hline & \multicolumn{1}{c}{ Safe Asset } & \multicolumn{1}{c}{ Quasi-safe asset } \\
\hline Universally & $\begin{array}{l}\text { High-quality public debt } \\
\text { (e.g., government bonds) }\end{array}$ & $\begin{array}{l}\text { Low-quality public debt and high-quality } \\
\text { private debt (e.g, MBS or bank deposits) }\end{array}$ \\
$\begin{array}{lll}\text { Not universally } \\
\text { accessible }\end{array}$ & Central bank reserves & $\begin{array}{l}\text { Exclusive and high-quality private invest- } \\
\text { ment vehicles (e.g., closed-end funds) }\end{array}$ \\
\hline
\end{tabular}

\subsection{Balance sheet framework}

In this section, we offer a formal presentation of the safe asset illusion. We develop a simple balance sheet framework to show how QE affects the (1) total amount, (2) sectoral holdings, and (3) composition of safe assets. ${ }^{3}$ Arguably, similar effects may arise from conventional or other unconventional monetary policy measures such as open market operations and (long-term) refinancing operations. However, there are still several difference: QE is typically at least an order of magnitude larger than open market operations or conventional refinancing operations. Additionally, it targets the core set of safe assets in the economy and it is an outright purchase of these assets instead of "only" a repo, like the ECB's long-term refinancing

\footnotetext{
${ }^{3}$ Recall, that "composition of safe assets " stands for the share of universally accessible and non-accessible safe assets.
} 
operations.

Our economy consists of three sectors: the central bank, a banking sector, and a non-bank sector. The distinguishing feature between a bank and non-bank is the access to the balance sheet of the central bank. Hence, what we mean by a bank is any institution with an account at the central bank. This might include entities without a banking license. In the U.S., for instance, some government-sponsored enterprises and money market funds have access to the Federal Reserve. Similarly, we define non-banks as institutions that do not have access to the balance sheet of the central bank. This includes households, non-financial corporations, insurance companies, money market funds (in the euro area), hedge funds, pension funds, etc. In particular, also foreign banks fall into that category.

There are three assets: government bonds $G$, reserves $R$, and bank deposits $D$. Government bonds are in positive net supply, which is exogenous: ${ }^{4}$

$$
G=G_{C B}+G_{B A}+G_{N B}
$$

where $G_{C B}, G_{B A}, G_{N B}$ are the government bond holdings of the central bank, banking sector, and non-bank sector, respectively. The other assets are in zero net supply, meaning they are a liability of one of the sectors in our economy. In line with our definition in Section 2.1, we categorize central bank reserves as safe assets and bank deposits as quasi-safe assets. Government bonds can be safe or quasi-safe. We assume the fraction $\rho$ of government bonds to be safe and $(1-\rho)$ to be quasi-safe.

\footnotetext{
${ }^{4}$ Note, that in the classical macro literature, the central bank and the government are usually one and the same. In our case, it makes sense to distinguish between the two because - at least in the short run - the central bank's decision to purchase government bonds is unrelated to the government's decision to increase or decrease its debt level.
} 
Figure 1 presents stylized balance sheets of our sectors. As government bonds are in positive net supply, they are held as an asset by all three sectors. The central bank issues reserves, which can only be held by the banking sector. The banking sector issues unsecured deposits that are held by the non-bank sector.

Figure 1: Sectoral balance sheets

Figure 1 shows the balance sheet of the central bank, the banking sector, and the non-bank sector.
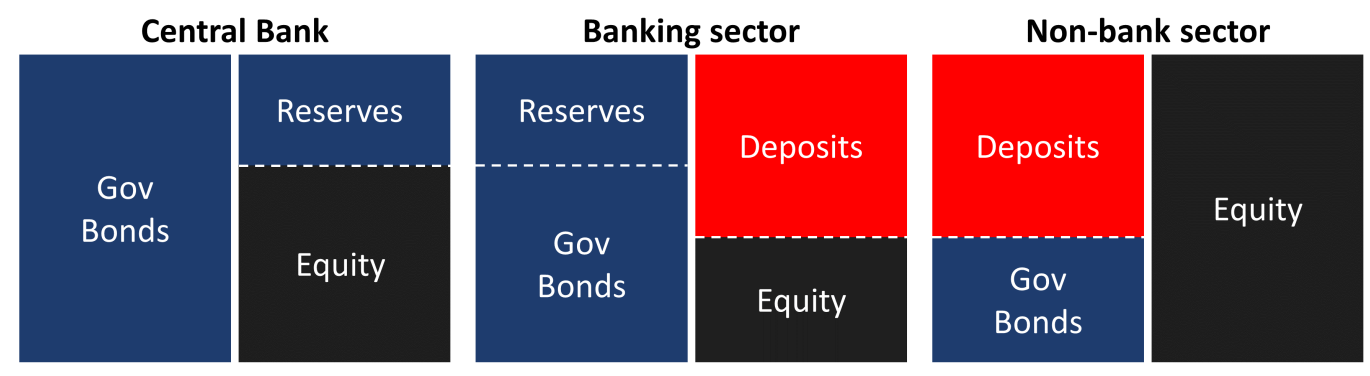

The balance sheets of the central bank, banking sector, and non-bank sector can be written as:

$$
\begin{array}{ll}
\mathrm{CB}: & G_{C B}=R+E_{C B}, \\
\mathrm{BA}: & G_{B A}+R=D+E_{B A} \\
\mathrm{NB}: & G_{N B}+D=E_{N B} .
\end{array}
$$

Based on this framework, we examine the effects of large-scale government bond purchases by the central bank on the holdings of safe and quasi-safe assets across the different sectors.

Figure 2 illustrates the impact of QE on the sectoral balance sheets. The central bank purchases government bonds from the banking and non-bank sector in the 
secondary market against reserves, i.e., $\Delta R=\Delta G_{C B}$. For simplicity, we assume that the total amount of government debt $G$ is unaffected by these purchases, i.e., $\Delta G=0$. Consequently, the increase in bond holdings at the central bank has to be offset by a decrease in the holdings of the banking and/or non-bank sector. We assume that a fraction $\gamma$ of the purchased bonds comes from the banking sector and $1-\gamma$ from the non-bank sector. The variable $\gamma$ is a reduced-form parameter that reflects the preferences of banks and non-banks to hold government bonds. ${ }^{5}$ Using the budget constraint, Equation (1), we can write: $\Delta R=\gamma \Delta G_{C B}+(1-\gamma) \Delta G_{C B}$.

Figure 2: Sectoral balance sheets during QE

Figure 2 shows how the balance sheets of the central bank, the banking sector, and the non-bank sector are affected through government bond purchases by the central bank.
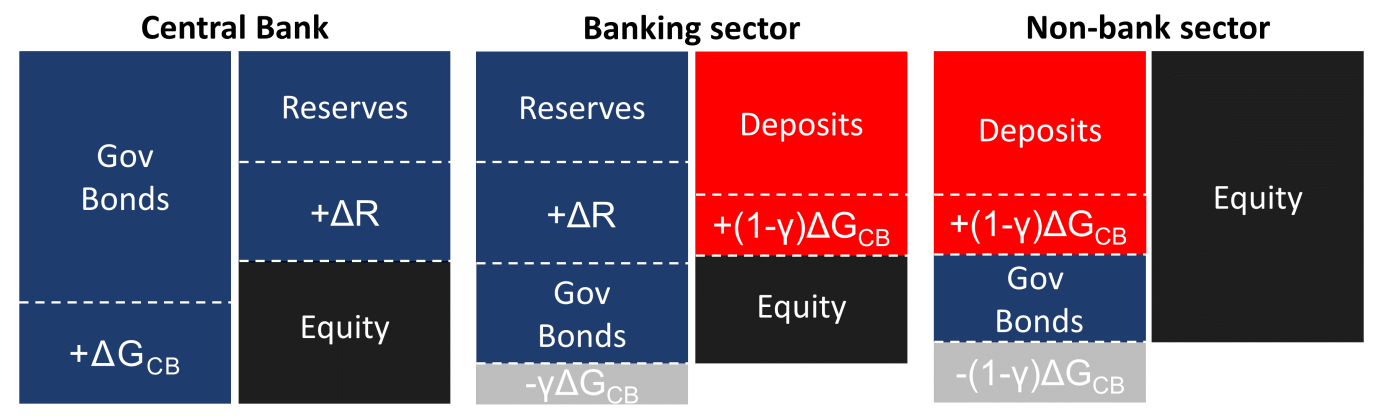

Figure 2 highlights several interesting facts: First, the central bank extends its balance sheet by purchasing $\Delta G_{C B}$ government bonds using newly created reserves $\Delta R$. Second, the banking sector receives $100 \%$ of the newly created reserves. Hence, for any $\gamma<1$, the balance sheet of the banking sector increases as a consequence of QE. Third, the non-bank sector sells $(1-\gamma) \Delta G_{C B}$ government bonds through

\footnotetext{
${ }^{5}$ The term preference should be taken in a broad sense. It encompasses the willingness but also the requirement to hold safe assets; for example, laws and regulations might prescribe to invest a certain amount in government bonds.
} 
the banking sector, which acts as intermediary. In return, non-banks receive bank deposits such that the size of the balance sheet of the non-bank sector remains constant. Lastly, the banking sector's role as intermediary has two interesting implications: (i) The increase in bank deposits is exogenous to banks. More precisely, the banking sector has to increase the amount of deposits if non-banks decide to sell government bonds to the central bank. (ii) Similarly, the amount of reserves in the banking sector is at least partially exogenous. The sector as a whole cannot avoid holding reserves as long as non-banks sell government bonds to the central bank. The extent to which the non-bank sector sells government bonds - and hence the extent to which both deposits and reserves increase - is determined by $(1-\gamma)$, i.e, the preference of non-banks to hold government bonds. In our empirical analysis we will estimate this parameter for euro area non-banks.

Table 2 summarizes the impact of QE on the total and sectoral holdings as well as the composition of safe assets. Derivations can be found in Appendix A.1.1. The banking sector sells $\rho \gamma \Delta G_{C B}$ government bonds and receives $\Delta R=\Delta G_{C B}$ reserves in return. The non-bank sector sells $\rho(1-\gamma) \Delta G_{C B}$ government bonds and receives only quasi-safe assets in return because it is compensated in the form of bank deposits. Hence, there is a transfer of safe assets from the non-bank to the banking sector. ${ }^{6}$ The change in the total amount of safe assets is $(1-\rho) \Delta G_{C B}$. Consequently, the central bank can determine the total amount of safe assets by setting $\rho$, but it cannot directly steer the sectoral holdings of safe assets because sectoral holdings (also) depend on the preferences of banks and non-banks to hold safe assets, $\gamma$. Finally, the first column of Table 2 shows that the change in the

\footnotetext{
${ }^{6}$ To keep the discussion simple, we abstract from possible government guarantees on bank deposits. The general SAI mechanism remains essentially the same.
} 
total amount of safe assets is composed of an increase in non-universally accessible safe assets and a decrease in universally accessible safe assets. The former increase by $\Delta R=\Delta G_{C B}$ and the latter decrease by $\rho \Delta G_{C B}$.

Table 2 also presents the changes of the total and sectoral holdings of quasi-safe asset. The holdings of the banking sector decrease by $(1-\rho) \gamma \Delta G_{C B}$, i.e., the amount of quasi-safe government bonds sold by banks. In case of the non-bank sector, the quasi-safe asset holdings increase by $\rho(1-\gamma) \Delta G_{C B}$, i.e., the amount of safe government bonds sold. This is due to the fact that non-banks only receive bank deposits when selling safe government bonds. Additionally, the quasi-safe asset holdings of non-banks do not change if they sell quasi-safe government bonds because such a transaction would simply be a swap of two quasi-safe assets (quasisafe government bonds against bank deposits). In sum, whether the total amount of quasi-safe assets increases or decreases depends on the relative size of the policy parameter $\rho$ that is determined by the central bank and the preference parameter $\gamma$ that differs across economic agents. ${ }^{7}$ The more safe assets are purchased by the central bank (high $\rho$ ) and from the non-bank sector (small $\gamma$ ), the higher the increase of quasi-safe assets.

In order to derive a measure for the preference of different sectors $s$ to hold government bonds, we introduce $\gamma^{s}$, where $s \in\{$ Bank, ICPF, OFI, HH, Other, Foreign $\}$ and $\sum_{s} \gamma^{s}=1 .{ }^{8}$ Against this background, we use

$$
\frac{\Delta G_{\text {safe }}^{\text {safe }}}{G_{\text {safe }}^{s}}=-\frac{\rho \gamma^{s} \Delta G_{C B}}{G_{\text {safe }}^{s}}
$$

\footnotetext{
${ }^{7}$ In the euro area, $\rho$ is determined by the ECB capital key of the individual member countries.

${ }^{8}$ Insurance companies and pension funds (ICPF), other financial institutions (OFI), households $(\mathrm{HH})$, others (Other), and foreign institutions (Foreign) are the non-bank sectors in our data, which we introduce in more detail in Section 3.
} 
Table 2: Change in total and sectoral holdings of (quasi-)safe assets

Table 2 presents the changes in total and sectoral holdings of safe and quasi-safe assets. Derivations can be found in the Appendix.

\begin{tabular}{lcl} 
& \multicolumn{1}{c}{ Safe assets } & Quasi-safe assets \\
\hline Banking sector & $(1-\rho \gamma) \Delta G_{C B}$ & $-(1-\rho) \gamma \Delta G_{C B}$ \\
Non-bank sector & $-\rho(1-\gamma) \Delta G_{C B}$ & $\rho(1-\gamma) \Delta G_{C B}$ \\
\hline Total & $(1-\rho) \Delta G_{C B}$ & $(\rho-\gamma) \Delta G_{C B}$
\end{tabular}

as a measure for the cross-sectional variation in the preference to hold safe government bonds. We can do this because the only driver of cross-sectional variation in this measure is variation in $\gamma^{s}$. When bringing this measure to the data, we still need to correct for the fact that the amount of outstanding government bonds also changes due to the issuance of new bonds. We derive this measure in an extension of the framework in the Appendix. While adding the issuance of new government bonds to the framework is necessary to make it fully transparent how our measure can be brought to SHSS data, nothing changes from a conceptual point of view. Since the extension adds some complexity without changing the overall picture, we decided to move it to the appendix.

We can now use the results presented in Table 2 to derive conditions for the neutrality of QE for (1) the total amount, (2) the sectoral holdings, and (3) the composition of safe assets.

\section{Proposition 1 (Safe asset neutrality of QE)}

(i) QE is neutral to the total amount of safe assets if $\rho=1$, i.e., if the central bank purchases only safe government bonds.

(ii) $Q E$ is neutral to the sectoral holdings of safe assets if $\rho=\gamma=1$, i.e., if the 
central bank purchases only safe government bonds and only from banks.

(iii) $Q E$ is never neutral to the composition of safe assets, i.e., to the share of universally accessible and non-accessible safe asset.

First, the central bank can steer the total amount of safe assets in the economy by specifying a particular value for $\rho$. In particular, if the central bank wants to stay safe asset-neutral, it can set the value of $\rho$ to one and hence purchase only safe government bonds. In this case, QE boils down to a swap of two forms of safe assets: safe government bonds and reserves. Second, the neutrality of QE for sectoral holdings depends on the (relative) preference of the banking and non-bank sector to hold safe government bonds. Neutrality is guaranteed if $\rho=\gamma=1$, i.e., if the central bank purchases only safe assets and only from banks, e.g. when only banks are willing to sell these assets. In this case, the balance sheet of the non-bank sector remains unchanged and the banking sector swaps one safe asset (safe government bonds) for another (central bank reserves). Third, QE can never be neutral to the composition of safe assets. The central bank always exchanges reserves for government bonds and hence a non-universally accessible safe asset for one that is universally accessible.

In a nutshell, the policy parameter $\rho$ and preference parameter $\gamma$ jointly determine the change in total and sectoral safe asset holdings. The central bank can affect the total amount of safe assets in the economy by setting $\rho$. However, the amount of quasi-safe assets and in particular the sectoral distribution of safe assets are (also) determined by $\gamma$, i.e., the banking and non-bank sector's preferences to hold government bonds. Consequently, knowing $\gamma$ is important for the central bank in order to assess the implications of its QE program for the sectoral holdings of 
safe assets. In the Appendix, we discuss several boundary cases for $\rho$ and $\gamma$.

\section{Empirical analysis}

In this section, we bring our balance sheet framework to data from the euro area in order to examine the (non-)neutrality of the PSPP for safe assets and quantify the effects. We measure changes in total and sectoral holdings of safe assets as well as their composition between March 2015 and December 2018.

\subsection{Public Sector Purchase Programme}

The PSPP was formally announced in January 2015 and further implementation details were communicated in March 2015, which marks also the start date of the large scale asset purchase program of the euro area. The policy rationale of the PSPP was to provide additional monetary policy accommodation in a situation in which policy rates could not be cut (much) further (the deposit facility rate had reached a level of -0.20 percent and the main refinancing rate stood at 0 percent).

The initial monthly envelope of PSPP purchases was EUR 60 billion, which was increased in April 2016 to EUR 80 billion and then decreased again to EUR 60 billion in April 2017. Between March 2015 and December 2018, the Eurosystem has purchased EUR 2.2 trillion of euro area government bonds, agency bonds and euro area supras (e.g., EIB bonds). ${ }^{9}$ The purchase volumes were split according to the capital key. In other words, each national central bank of the Eurosystem purchased the share of the monthly PSPP envelope that corresponds to its capital

\footnotetext{
${ }^{9}$ Cumulative net purchase figures in this sub-section represent the difference between the acquisition cost of all purchase operations and the redeemed nominal amounts.
} 
share, exclusively focusing on the govenment bonds of their own country.

As of 31 December 2018, out of the total PSPP purchase volume, the Eurosystem had acquired EUR 519 billion in German, EUR 420 billion in French, EUR 365 billion in Italian, EUR 261 billion in Spanish and EUR 115 billion in Dutch public sector bonds, corresponding to $26.1 \%, 18.3 \%, 16.9 \%, 21.8 \%, 24.5 \%$ of all outstanding bonds of these countries.

\subsection{Data description}

We use data from the Securities Holdings Statistics by Sector (SHSS) database which provides information on holdings of securities by euro area resident sectors. In our sample, debt securities are identified by a unique International Securities Identifier Number (ISIN) and the total reported holdings of these securities per quarter are approximately EUR 19 trillion in nominal value. We merge the SHSS data with the nominal value of the asset purchase programme (APP) holdings of the Eurosystem at the security level and quarterly frequency, amounting to a total of around EUR 2.4 trillion in Q4 2018. In addition, we enrich the database with security level characteristics and outstanding amounts from the Centralised Securities Database (CSDB), and complement the CSDB data with data on credit ratings given by DBRS, Fitch, Moodys and Standard and Poors. When no sovereignand ISIN-level credit ratings are available, we use issuer-level credit ratings based on characteristics of the ISINs. Our sample spans from Q2 2014 until Q4 2018.

Following Koijen et al. (2020), we group the SHSS holdings sectors into five euro area sectors: monetary financial institutions (MFI, or: Banks), insurance corporations and pensions funds (ICPF), other financial institutions (OFI) which 
includes money market funds, investment funds and other financial corporations, households (HH), and government and non-financial corporations (Other). We also add the Eurosystem sector characterised by the APP holdings. Finally we create the foreign sector (Foreign) - that is, non-euro area investors - as the residual obtained from the difference between the total outstanding amount of a given security and the aggregate holdings of the corresponding security by euro area sectors. ${ }^{10}$ In addition, as CSDB should cover the full universe of euro-denominated securities issued by euro area entities, we assign the total outstanding amount of those securities of interest not included in the SHSS to the foreign sector.

We distinguish the assets covered in our sample between both government and corporate bonds, asset-backed securities and covered bonds. For the purpose of our analysis, we focus on euro-denominated government debt securities issued by euro area legal entities, including agency bonds and supras held under the PSPP. To this end, we use the CSDB characteristics to filter out securities that are still alive in the investors' holdings portfolio and classify them according to their debt type. ${ }^{11}$ Thus, total nominal holdings of government debt securities amount to approximately EUR 8.3 trillion on average over our review period. In addition, holdings by the Eurosystem sector only comprise the PSPP purchases.

\footnotetext{
${ }^{10} \mathrm{~A}$ shortcoming of the SHSS data is the difficulty of measuring securities positions of investors located outside the euro area - also known as custodial bias - as foreign holdings are reported to a large extent indirectly via euro area custodians which may then not pick up the country of the final investor. Thus, holdings by the foreign sector are treated as a residual category to match the aggregate outstanding nominal amount of the securities of interest.

${ }^{11}$ Securities that have not been redeemed yet, but have a negative residual maturity, can still be reported in the investors' holdings portfolio. We do not include securities with negative residual maturity according to CSDB.
} 


\subsection{Measuring safe asset volumes}

Before we are able to quantify the change in the composition of safe assets in the euro area, we need to operationalize our definition of safe assets. The first requirement for an asset to be universally safe is that it is issued or backed by the government. This excludes private debt. But even in the case of public debt there exists significant heterogeneity in the cross-section of safety and we cannot classify $100 \%$ of euro area public debt as safe. Instead, we use sovereign credit ratings to distinguish between safe and quasi-safe public debt. In our baseline definition, we classify public debt issued by sovereigns with at least an AA credit rating as safe; this includes debt from the following countries: Germany, France, the Netherlands, Finland, Austria, Belgium, and Luxembourg. ${ }^{12}$ Finally, we define central bank reserves as universally safe.

Figure 3 shows the evolution of average CDS spreads over our sample period for euro area sovereign bonds falling into either the safe or quasi-safe asset category. The variability of (traded) credit risk is much lower for safe assets than for quasi-safe assets and - in line with the definition of quasi-safeness - there are states of the world during which quasi-safe assets experience significant shocks to their perceived safeness while safe assets remain relatively unaffected.

\subsection{Safe asset rebalancing}

In order to examine the (non-)neutrality of the PSPP to safe assets, we measure the changes in total and sectoral holdings of safe assets using SHSS data. The first three columns of Table 3 summarize safe asset rebalancing across our sectors from

\footnotetext{
${ }^{12}$ As a robustness check, we examine how our results change if we define only German government bonds as safe.
} 
Figure 3: CDS rates of safe and quasi-safe assets

Figure 3 presents average CDS rates of safe and quasi-safe assets in the euro area.

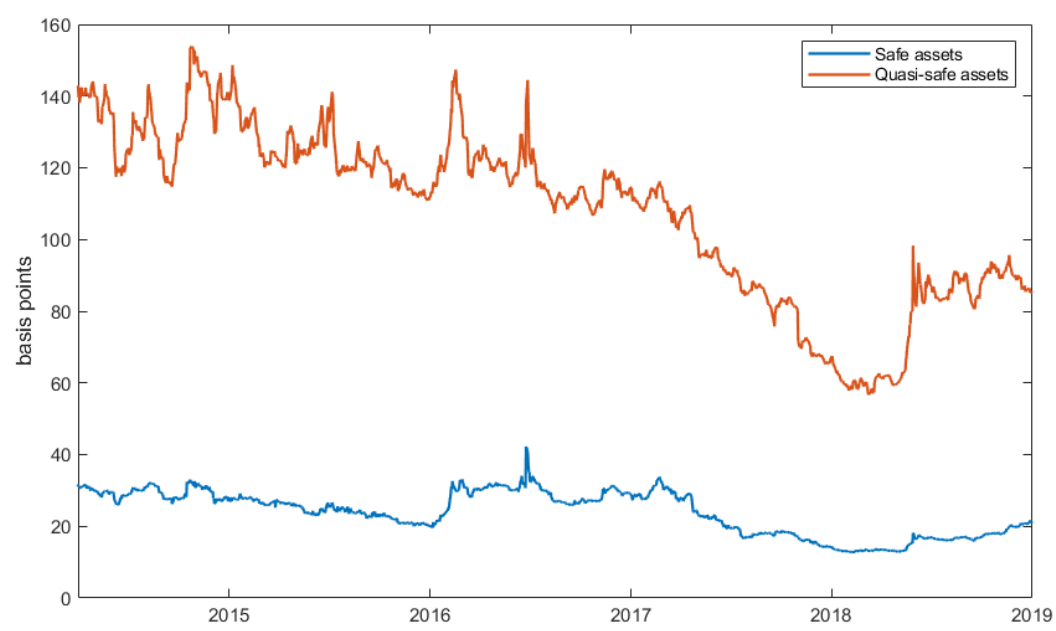

Q1 2015 to Q4 2018. The first column shows the cumulative changes in reserve holdings of the banking sector as a share of euro area GDP. Reserve holdings increases strongly because banks receive reserves irrespective of which sector sells safe and quasi-safe government bonds to the ECB. ${ }^{13}$

The second column summarizes the rebalancing of safe government bonds as a share of euro area GDP. The ECB purchases $11.1 \%$ of safe government bonds from the banking and non-bank sector. Banks decrease their holdings by $3.4 \%$ and non-banks by $4.4 \%$, leading to a total reduction in safe government bonds of $7.8 \%$. The difference between this reduction and the ECB purchases amounts to $3.3 \%$, which is the positive net issuance of additional safe government bonds by euro

\footnotetext{
${ }^{13}$ Since the PSPP has not been the only purchase program and since there are other drivers of reserve holdings, the change in reserves deviates from the total PSPP purchase volume (14.3\% vs. $16.7 \%$ as a share of euro area GDP). Hence, the assumption $\Delta R=\Delta G$ from the balance sheet model does not hold and therefore we use the change in reserve holding $\Delta R$ directly to measure the change in safe asset holdings.
} 
area governments as a share of GDP. There is significant variation in rebalancing activity across sectors. The foreign sector is the biggest seller of government bonds, closely followed by banks. Insurance companies and pension funds, on the other hand, even increase their government bond holdings.

The third column presents the relative changes in safe government bond holdings $\Delta G_{\text {safe }}^{s}$, where $s \in\{$ Bank,ICPF,OFI,HH,Other, Foreign $\}$; it serves as our measure of the cross-sectional variation in the preference to hold government bonds. The higher $\frac{\Delta G^{s}}{G^{s}}$, the more willing a sector is to hold safe government bonds. In the Appendix, we show that the cross-sectional variation of this measure purely arises from variation in $\gamma$ and $\kappa$, that is, in the preference to hold safe assets (see, Equation (17)). Banks, households, and the foreign sector have the lowest preference to hold safe government bonds.

The changes in total and sectoral holdings of safe assets are in line with the safe asset illusion. The PSPP is neither neutral to the total amount, nor to sectoral holdings or the composition of safe assets. Panel (a) of Figure 4 plots the holdings of safe assets across different sectors as a share of GDP between July 2014 December 2018. The total amount of safe assets increases from 49\% in Q1 2015 to 55\% in Q4 2018. This increase is mainly driven by a strong increase in reserve holdings of the banking sector.

Panel (a) of Figure 4 also shows that the PSPP triggers a change in the crosssectional distribution of safe assets: The banking sector increases its holdings of safe assets at the expense of non-banks, in particular the foreign sector. The driver of the increase in the safe asset holdings of the banking sector is the increase in reserve holdings. It more than outweighs banks' decrease of safe government bond holdings because banks do not only receive reserves when selling their own safe government 
Table 3: Safe asset rebalancing

Table 3 shows the cumulative rebalancing as a share of euro area real GDP (in percent) from Q1 2015 to Q4 2018 of safe assets (reserves and government bonds rated at least AA), German government bonds, and government bonds rated lower than AA. The third, fifth, and seventh column present relative changes (in percent), which serve as a proxy for the cross-sectional variation in the preference of holing these assets. The top panel reports the rebalancing of the banking and non-bank sector, distinguishing between the five non-bank categories. The second panel reports the rebalancing of the Eurosystem and the bottom panel reports net issuances.

\begin{tabular}{|c|c|c|c|c|c|c|c|}
\hline \multirow[b]{2}{*}{ Sector } & \multicolumn{3}{|c|}{ Safe assets } & \multicolumn{2}{|c|}{ Gov bonds (DE) } & \multicolumn{2}{|c|}{ Gov bonds $(<\mathrm{AA})$} \\
\hline & $\Delta \frac{R}{G D P}$ & $\Delta \frac{G^{s}}{G D P}$ & $\frac{\Delta G^{s}}{G^{s}}$ & $\Delta \frac{G^{s}}{G D P}$ & $\frac{\Delta G^{s}}{G^{s}}$ & $\Delta \frac{G^{s}}{G D P}$ & $\frac{\Delta G^{s}}{G^{s}}$ \\
\hline Banks & 14.33 & -3.42 & -30.89 & -1.31 & -32.98 & -1.22 & -6.95 \\
\hline Non-banks & & -4.43 & -4.77 & -1.59 & -5.16 & -1.77 & -1.92 \\
\hline OFI & & -0.07 & 6.76 & -0.10 & 2.04 & -1.11 & -14.93 \\
\hline $\mathrm{ICPF}$ & & 0.65 & 16.46 & 0.14 & 21.53 & 0.88 & 25.33 \\
\hline $\mathrm{HH}$ & & -0.12 & -39.54 & -0.07 & -44.18 & -0.47 & -19.49 \\
\hline Other & & -0.07 & 3.91 & 0.00 & 8.68 & -0.39 & -19.48 \\
\hline Foreign & & -4.83 & -16.27 & -1.56 & -10.82 & -0.68 & -7.07 \\
\hline Eurosystem & & 11.10 & & 4.01 & & 5.60 & \\
\hline Total & 14.33 & 3.26 & & 1.11 & & 2.61 & \\
\hline
\end{tabular}

bonds, but also when selling their quasi-safe bonds and when selling bonds for their customers. The holdings of insurance companies and pension funds remain stable. The holdings of households and other non-bank entities are negligible.

Finally, Panel (b) of Figure 4 shows that the PSPP also affects the composition of safe assets. It presents the holdings of universally accessible safe assets. The total amount of these assets decreases from 46\% of euro area GDP in Q1 2015 to $39 \%$ in Q4 2018. Consequently, the amount of safe assets that are not universally accessible (that is, reserves) increases at the expense of universally accessible safe 
assets (that is, government bonds).

Figure 4: Safe asset rebalancing

Panel (a) of Figure 4 presents the safe asset holdings of the banking and the different non-bank sectors as a share of GDP. For banks, we distinguish between government bond holdings (dark grey) and reserves (light grey). Reserves are measured as the outstanding amount of excess liquidity (EL), which is defined as the reserve holdings of euro area banks at the ECB above and beyond the minimum reserve requirements. Panel (b) shows the universally accessible safe asset holdings of our sectors.

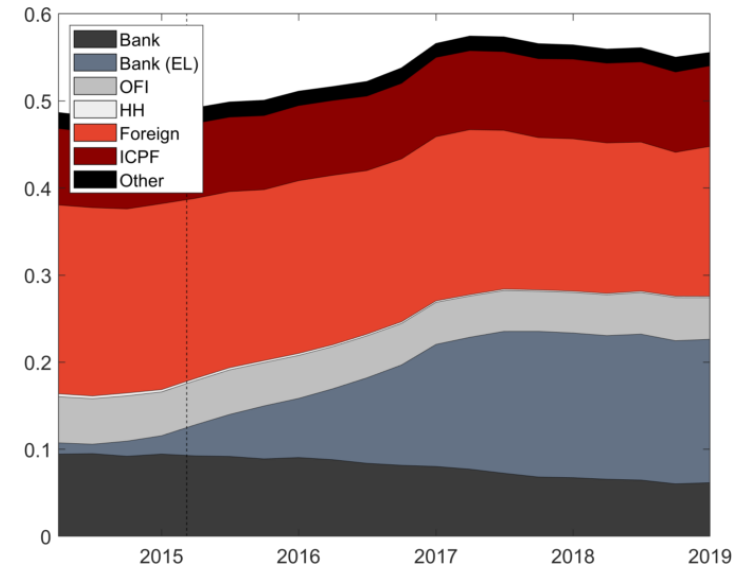

(a) Safe assets

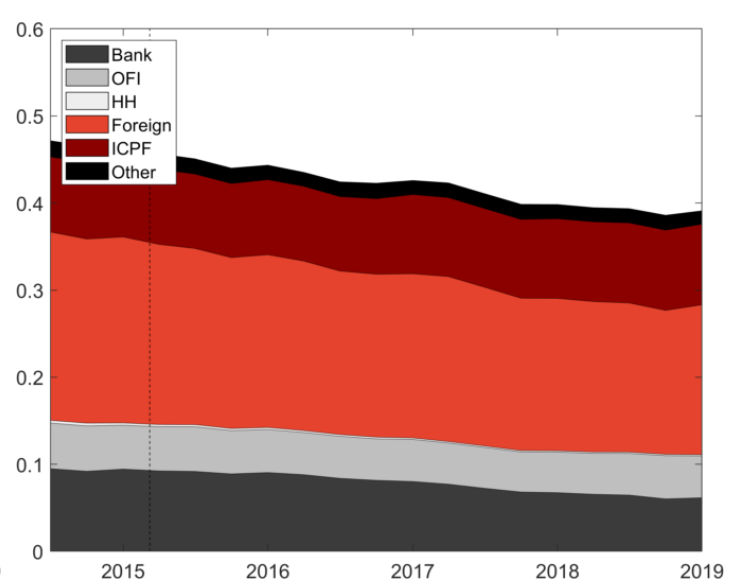

(b) Universally accessible safe assets

In particular, the cross-sectional variation in the rebalancing of safe assets is in line with the safe asset illusion. It is not surprising that especially banks, households, and foreign institutions are willing to reduce their safe government bond holdings. In other words - and as shown by the low values for $\frac{\Delta G^{s}}{G^{s}}$ - these sectors have a lower preference to hold safe government bonds because they have lower opportunity cost of holding these assets: Banks are in an exclusive position because they receive back another type of safe assets - that is, reserves - when selling government bonds. Households are willing to reduce their safe government bond holdings because the deposit insurance acts as a transformation technology for 
them, transforming a quasi-safe asset into a safe asset (up to 100,000 EUR, which is a meaningful size for the average household). Finally, the trade-off for the foreign sector is of a somewhat different nature because safe euro area government bonds can be replaced by a similar safe government bond from another jurisdiction-for example, US treasuries - without fundamentally changing the risk profile of the asset.

\subsection{Robustness checks}

The fourth and fifth column of Table 3 present the rebalancing volumes for German government bonds. ${ }^{14}$ These numbers serve as a robustness check to examine if our results change when applying a more restrictive definition of safe assets. The crosssectional variation of the preferences to hold safe government bonds - measured by $\frac{\Delta G^{s}}{G^{s}}$-is similar to our baseline results. Banks, households, and the foreign sector are most willing to reduce their safe government bond holdings.

The sixth and seventh column of Table 3 present the reblancing volumes for quasi-safe government bonds, that is, bonds rated lower than AA. The crosssectional variation in the preferences to hold these bonds differs from our baseline results. Except for insurance companies and pension funds, which increase their holdings of quasi-safe bonds, all other sectors reduce their holdings. These results support our approach to measuring safe and quasi-safe assets using AA as a rating threshold. There seems to be a difference in the rebalancing behavior between government bonds with ratings above and below this threshold.

\footnotetext{
${ }^{14}$ German government bonds follow the same definition as overall government bonds, including German agency bonds held under the PSPP.
} 


\section{Implications of the safe asset illusion}

In this section, we discuss two main implications of the safe asset illusion: First, we analyze the premium that non-banks have to pay for safely storing their liquidity. There are two main ways to safely store liquidity: central bank reserves and general collateral (GC) repurchase agreements (repos). While banks can rely on both, non-banks cannot access the central bank deposit facility and therefore they have to pay a premium to ensure that their liquidity is stored safely. Second, we show that the PSPP reduces the collateral quality in the money market, which may adversely impact financial stability.

\subsection{Distributional consequences for the banking and non- bank sector: safe storage premium}

The GC repo market with safe assets as collateral is one of very few - if not the only-possibilities for non-banks to deposit their short-term liquidity nearly without risk. ${ }^{15}$ A GC repo is conceptually identical to a (very) short-term secured loan. Hence, the cash-rich agent lends its funds to (or deposits with) a cash-seeking agent at a predefined rate and maturity against collateral.

Since the start of the PSPP, however, the repo rate has fallen strongly, in particular for repos backed by safe assets. Extant literature suggests that largescale government bond purchases render safe assets scarce, which is reflected in

\footnotetext{
${ }^{15}$ There are other financial instruments for holding liquid positions such as certificates of deposit and savings or money market accounts. However, (reverse) repos secured by safe assets represent the safest option for lending with very short maturities. The asset being used as collateral can be a particular asset (special collateral or SC repos) or any asset from a predefined basket of assets (general collateral or GC repos). We focus on GC repos because this is the market segment that is used to manage liquidity, while SC repos are rather used to borrow or lend securities.
} 
lower rates for these assets in the repo market (e.g., D'Amico, Fan, and Kitsul, 2018; Arrata et al., 2020; Corradin and Maddaloni, 2020). Therefore, it has become more and more expensive to store short-term liquidity safely. For banks, the deposit facility rate (DFR) is a lower bound for the rate they accept to deposit their cash. Hence, if the repo rate drops below the DFR, banks have a strong incentive to deposit their cash at the deposit facility instead of using the repo market. Non-banks on the other hand do not have access to this facility. Their main alternative to a bank deposit is the repo market, which increases their safe storage cost relative to that of banks, creating a safe storage premium. This premium can be interpreted as a convenience yield that originates due to a market segmentation in the market for reserves. The safe asset literature points to two main determinants of the convenience yield: a safety and a liquidity premium (e.g., Krishnamurthy and Vissing-Jorgensen, 2012; Sunderam, 2015; Gorton, 2017), which in turn increases with the opportunity cost of holding money (Nagel, 2016). The segmentation inherent in the monetary policy setting granting the access only to banks induces non-banks to pay a convenience yield for holding liquidity safely.

Figure 5 plots the rate on the ECB's deposit facility together with the overnight rate on euro GC repos backed by safe euro area government bonds (blue) and German government bonds (black). ${ }^{16}$ In an overnight GC repo, the non-bank deposits cash overnight in return for a government bond. The transaction is reversed the next day. Both the DFR and GC repo rate have moved to negative territory already in 2014. Additionally, the repo rate has dropped below the DFR shortly after the start of the PSPP and stayed there ever since. Hence, since at

\footnotetext{
${ }^{16}$ We collect the underlying data from the three major repo exchanges in the euro area: BrokerTec, Eurex, and MTS. For a more detailed description of the market and this dataset, see Ranaldo, Schaffner, and Vasios (2020).
} 
least mid-2015 non-banks have to pay a premium to store their overnight liquidity safely. Between March 2015 and December 2018, this premium has averaged 7 basis points for safe government bonds and 10 basis points for German government bonds.

These costs likely represent a lower bound estimate for the costs of non-banks for a GC repo as these rates are those observed on large platforms which typically do not have non-banks among their customers. Eisenschmidt, Ma, and Zhang (2020) show that non-banks can access the repo market only at significantly higher costs than banks. Looking at repo rates in the OTC segment contained in the ECB's MMSR statistic allows separating repo trades according to their counterparty. Repo spreads paid by non-banks are significantly higher than those paid by banks, with non-banks paying between 10 - 15 basis points higher rates than banks, although the drawback of the approach is that a clean separation between GC and SC repos is not possible and the estimated spread between non-banks and banks may be biased upwards. In any case, the reported premia are substantial given the very low interest rates in the money market. If banks had to store their liquidity in the GC repo market, that is, they would have to pay a similar type of premium as non-banks to safely store their reserves, they would have faced additional cost of EUR 3.3 - 4.7 billion between March 2015 and December 2018. ${ }^{17}$ Consequently, the market segmentation in the market for central bank reserves creates a wedge between the banking and non-bank sector when it comes to the costs of safely storing cash.

\footnotetext{
${ }^{17}$ Computed as average amount of excess liquidity times 7 basis points (lower bound) and 10 basis points (upper bound) annualized interest rate spread for the period March 2015 - December 2018. Recall that excess liquidity is defined as the reserve holdings of euro area banks at the ECB above and beyond the minimum reserve requirements.
} 
Figure 5: The safe storage premium

Figure 5 plots the rate on the ECB's deposit facility rate together with the rate on general collateral repurchase agreements backed by safe government bonds (blue) and German government bonds (black). The dotted vertical line marks the start of the PSPP purchases in March 2015.

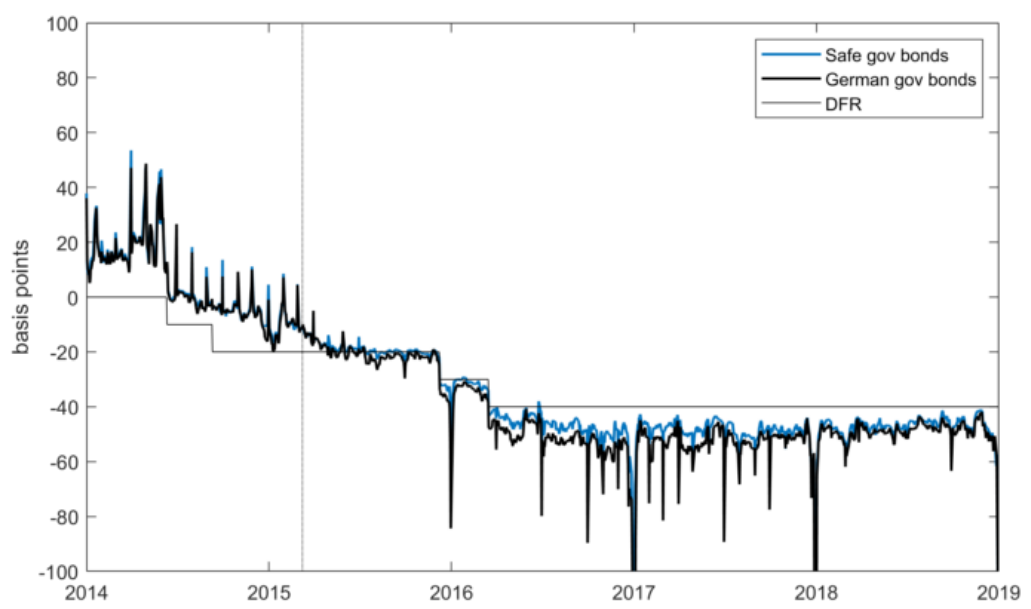

\subsection{Fragile liquidity}

In this section, we show that due to the PSPP, the overall quality of collateral in the money market decreases. The rationale behind this development is straight-forward: With the start of the PSPP, the share of universally accessible safe assets steadily decreases because the ECB acts as buy and hold investor of safe government bonds. In particular, the ECB purchases more safe than quasi-safe government bonds (in absolut and relative terms). This reduction in the relative supply of safe government bonds is reflected in the use of these assets as collateral in the money market. The consequent substitution from safe to quasi-safe collateral is important because it contributes to financial fragility.

Figure 6 plots the trading volume of overnight euro GC repos traded on the three major exchanges in the euro area (BrokerTec, Eurex, and MTS). The figure distinguishes between repos backed by safe and quasi-safe government bonds. Before 
the start of the PSPP purchases - indicated by the dotted vertical line - cumulated trading volumes of repos backed by quasi-safe assets were slightly below those backed by safe assets. After the start of the PSPP, repo volumes start to fall because of the additional excess liquidity in the system. However, trading volumes of repos backed by safe assets fall faster than those backed by quasi-safe assets. Thereby the collateral base in the repo market deteriorates, increasing the share of quasi-safe assets.

Figure 6: GC repo trading volumes

Figure 6 plots the repo trading volume of overnight euro GC repos collateralized by safe and quasi-safe assets. The data captures repos traded on the three major trading platforms in Europe: BrokerTec, Eurex, and MTS. The dotted vertical line marks the start of the PSPP purchases.

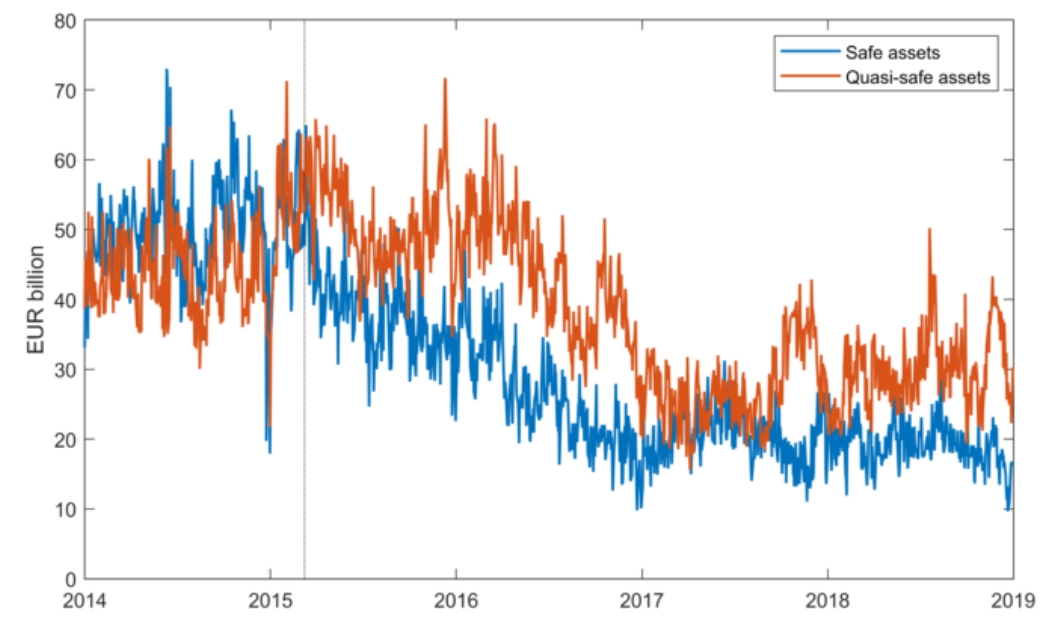

As discussed above, quasi-safe assets behave similarly to safe assets during normal times and even carry a convenience premium (e.g., Kacperczyk, Perignon, and Vuillemey, 2018). However, their convenience yield is wobbling because in bad times, their safety and liquidity attributes reduce or can even disappear swiftly. The main issue is that quasi-safe assets become information-sensitive as investors doubt the true value and risk of these assets. This mechanism also applies to 
quasi-safe assets used as collateral impairing their collateral value. Against this background, a collateral base consisting of a high share of quasi-safe assets leads to financial fragility (Gorton and Ordonez, 2014) or fragile liquidity (Moreira and Savov, 2017).

Table 4 presents summary statistics for the share of safe assets used as collateral in the euro repo market. Pre-PSPP captures the period before the start of the PSPP purchases from 1 January 2014 until 8 March 2015. The average share of safe collateral amounts to $53 \%$ during that period. The variation in the share of safe collateral is rather small with only $4.3 \%$. The PSPP period starts on 9 March 2015 and ends on 31 December 2018. The share of safe collateral used in money market transactions decreases significantly after the start of the PSPP. On average it is about $10 \%$ lower during the PSPP period than pre-PSPP. At the end of our sample in December 2018, the share of safe collateral is even below $30 \%$.

Table 4: Summary statistics for the share of safe collateral

Table 4 presents summary statistics for the share of safe assets used as collateral in the euro repo market. Pre-PSPP captures the period before the start of the PSPP purchases from 1 January 2014 until 8 March 2015. Post-PSPP captures the the period of PSPP purchases, starting on 9 March 2015 and ending on 31 December 2018.

\begin{tabular}{lllllll}
\hline Safe collateral share (\%) & Mean & Median & Std & Min & Max & N \\
\hline Pre-PSPP & 52.74 & 52.80 & 4.30 & 35.73 & 62.71 & 301 \\
& & & & & & \\
PSPP period & 40.41 & 40.36 & 6.21 & 23.55 & 58.98 & 977 \\
2015 (after 8 March) & 42.91 & 42.68 & 4.38 & 31.08 & 53.03 & 210 \\
2016 & 36.99 & 36.79 & 4.85 & 24.99 & 50.49 & 257 \\
2017 & 42.68 & 43.35 & 7.27 & 23.55 & 58.98 & 255 \\
2018 & 39.51 & 39.41 & 5.72 & 25.63 & 56.43 & 255 \\
\hline
\end{tabular}

Table 5 provides additional evidence for the relation between a reduction in the supply of safe government bonds through the PSPP and a decreasing share of 
safe collateral in the euro GC repo market. It presents the results of the following regression:

$$
\begin{aligned}
\Delta \text { Safe Col Share } & =\alpha+\beta \Delta \text { Safe Gov Bond Share } \\
& +\gamma_{1} \Delta i \operatorname{Trax} x_{t}+\gamma_{2} \Delta \operatorname{VSTOX} X_{t}+\gamma_{3} \Delta E L_{t}+\varepsilon_{t},
\end{aligned}
$$

where Safe Col Share is the safe collateral share in the euro GC repo market $\left(\frac{V o l_{t}^{S A}}{V o l_{t}^{T o t a l}}\right)$, Safe Gov Bond Share is the share of outstanding safe euro area government bonds, that is, the share of bonds that is available in the market and not (yet) held by the ECB $\left(\frac{\text { Outstanding }_{t}^{S A}}{\text { Outstanding }_{t}^{T o t a l}}\right) \cdot i \operatorname{Trax}_{t}$ is the iTraxx Europe. It captures variation in CDS spreads that might be caused by changes in market-wide credit or liquidity risk. $V S T O X X_{t}$ captures changes in expectations about aggregate volatility. It reflects the investor sentiment and overall economic uncertainty by measuring the 30-day implied volatility of the EURO STOXX 50. EL $L_{t}$ is the level of excess liquidity holdings. Including $E L_{t}$ enables us to control for potential changes in the demand for safe collateral that are driven by the need to safely store the additional liquidity from the PSPP. Finally, $\varepsilon_{t}$ is the error term. In order to ensure stationarity and to rule out spurious correlation, we take first differences of all variables. Additionally, we estimate Equation (6) using robust standard errors.

Since GC repo baskets only exist for selected euro area countries, we consider only the following countries in this analysis: Austria, Belgium, Germany, Finland, France, Luxembourg, the Netherlands (safe) and Spain, Greece, Ireland, and Portugal (quasi-safe). In order to control for end-of-quarter effects and eliminate problems stemming from extreme seasonalities common to repo markets, we exclude the last day of each quarter from the regression. Leaving these observations in does 
not qualitatively change any of the results.

Table 5: Fragile liquidity

Table 5 presents the results of regressing the safe collateral share in the euro GC repo market on the share of outstanding safe euro area government bonds-i.e., the share of bonds that is available in the market and not (yet) held by the ECB. $t$-statistics are shown in parentheses. The stars ${ }^{* * *},{ }^{* *}$, and ${ }^{*}$ indicate statistical significance at the $1 \%, 5 \%$, and $10 \%$ level, respectively.

\begin{tabular}{lcc}
\hline & & $(1)$ \\
& $\Delta$ Safe Col Share & $\Delta$ Safe Col Share \\
\hline$\Delta$ Safe Gov Bond Share & $3.953^{*}$ & $3.780^{*}$ \\
& $(1.79)$ & $(1.70)$ \\
$\Delta$ iTraxx Europe & & 0.00939 \\
& & $(0.10)$ \\
$\Delta$ VSTOXX & & -0.0116 \\
& & $(-0.08)$ \\
$\Delta$ Excess Liquidity (EURbn) & & $7.10 \mathrm{e}-06$ \\
& & $(0.53)$ \\
Constant & & -0.0191 \\
& & $(-0.13)$ \\
\hline $\mathrm{N}$ & $(-0.04)$ & 948 \\
$R^{2}$ & 948 & 0.00346 \\
$R_{\text {adj }}^{2}$ & 0.00314 & -0.000768 \\
\hline
\end{tabular}

Following the rationale above, a lower share of outstanding safe government bonds should lead to a lower share of safe collateral in the repo market. The first column of Table 5 confirms this hypothesis. If the share of safe government bonds decreases by $1 \%$, the share of safe collateral decreases by about $4 \%$. The second column shows that this result is robust to variation in aggregate measures of credit risk, volatility, and excess liquidity. 


\section{Conclusion}

We propose a simple balance sheet framework outlining the non-neutrality of largescale government bond purchases - known as Quantitative Easing, short: QE - to safe assets. We show that while QE increases the total amount of safe assets, it transfers safe assets from the non-bank to the banking sector and it decreases the amount of safe assets that are universally accessible. We call this phenomenon the safe asset illusion. In our empirical analysis, we show that during the ECB's Public Sector Purchase Programme - between Q1 2015 and Q4 2018 - the total amount of safe assets increases from $49 \%$ to $55 \%$ of euro area GDP. However, this increase is exclusively driven by newly issued central bank reserves and only the banking sector profits from it. The safe asset holdings of the non-bank sector decrease by $4.4 \%$ during the same period. Importantly, the total amount of universally accessible safe assets decreases from 46\% of euro area GDP in Q1 2015 to 39\% in Q4 2018, contributing significantly to the overall scarcity of safe assets in the euro area. We examine two implications of this safe asset scarcity for the distribution of wealth and financial stability: First, since non-banks do not have access to central bank reserves, they have to pay a premium for safely storing their liquidity. Second, the PSPP deteriorates the collateral quality in the money market.

The main friction behind the safe asset illusion is the market segmentation originating from granting only the banking sector access to the balance sheet of the central bank. This gives rise to several possible policy responses that can mitigate the adverse effects of the safe asset illusion: First, the ECB could extend the access to its reserves to a wider range of institutions. This would allow (parts of) the non-bank sector to profit from the possibility to safely and (relatively) cheaply 
store liquidity in the deposit facility (or a similar facility). Against this background, the debate around retail central bank digital currencies (CBDC) seems interesting because a retail CBDC would give all economic agents access to central bank money. Of course, the implications of a retail CBDC go far beyond its effect on safe assets. Nevertheless, it seems worth to include this dimension into the debate surrounding the introduction of a CBDC.

A second policy response to address the adverse effects of the safe asset illusion would be to increase the availability of universally accessible safe assets. For instance, the ECB could intensify its efforts to channel back safe assets into the market via its securities lending facility. Alternatively, it could issue its own safe assets, for instance, in form of ECB Debt Certificates (Hardy, 2020). Securities lending as well as ECB Debt Certificates would mitigate the scarcity of safe collateral in the repo market, leading to higher repo rates. Therefore, these policies could decrease the cost of safely storing liquidity for the institutions without access to the deposit facility.

The goal of this paper was to outline and document the effect of QE-in particular, of the PSPP — on the total amount, sectoral distribution, and composition of safe assets. Our findings raise a couple of interesting questions, which can be addressed by future research. For instance: Are banks profiting or suffering from the additional safe asset holdings? Since excess liquidity is remunerated at negative interest rates, it is open whether the net effect of additional safe assets is positive or negative for the banking sector. Moreover, the safe asset illusion suggests that the cross-sectional heterogeneity in the preferences to hold safe government bonds have important implications for the transmission efficiency of QE. Especially those sectors with high opportunity cost of holding safe assets are less willing to 
give these assets away. Against this background, it seems likely that the ex ante holding structure of government bonds matters for the efficiency of QE. If most of the government bonds are in the hands of sectors with a high preference to hold government bonds, the price impact of asset purchases might increase. 


\section{References}

Arrata, W., B. Nguyen, I. Rahmouni-Rousseau, and M. Vari. 2020. The scarcity effect of QE on repo rates: evidence from the euro area. Journal of Financial Economics 137:837-856.

Azzimonti, M., and P. Yared. 2018. The optimal public and private provision of safe assets. NBER Working Paper 24534.

Barro, R. J., J. Fernandez-Villaverde, O. Levintal, and A. Mollerus. 2017. Safe Assets. NBER Working Paper 20652:1-46.

Benigno, P., and S. Nisticò. 2017. Safe Assets, Liquidity, and Monetary Policy. American Economic Journal: Macroeconomics 9:182-227.

Caballero, B. R. J., E. Farhi, and P.-O. Gourinchas. 2008. An Equilibrium Model of "Global Imbalances" and Low Interest Rates. American Economic Review 98:358-393.

Caballero, R. J., and E. Farhi. 2018. The Safety Trap. Review of Economic Studies $85: 223-274$.

Caballero, R. J., E. Farhi, and P.-O. Gourinchas. 2017. The Safe Assets Shortage Conundrum. Journal of Economic Perspectives 31:29-46.

Caballero, R. J., and A. Krishnamurthy. 2009. Global Imbalances and Financial Fragility. American Economic Review Papers and Proceedings 99:584-588.

Christensen, J. H., and S. Krogstrup. 2019. Transmission of Quantitative Easing: The role of Central Bank Reserves. Economic Journal 129:249-272. 
Corradin, S., and A. Maddaloni. 2020. The importance of being special: Repo markets during the crisis. Journal of Financial Economics 137:392-429.

Cúrdia, V., and M. Woodford. 2011. The central-bank balance sheet as an instrument of monetary policy. Journal of Monetary Economics 58:54-79.

D'Amico, S., R. Fan, and Y. Kitsul. 2018. The Scarcity Value of Treasury Collateral: Repo-Market Effects of Security-Specific Supply and Demand Factors. Journal of Financial and Quantitative Analysis 53:2103-2129.

Dang, T. T. V., G. Gorton, and B. Holmström. 2015. The Information Sensitivity of a Security.

Eisenschmidt, J., Y. Ma, and A. L. Zhang. 2020. Monetary Policy Transmission in Segmented Markets.

Gertler, M., and N. Kiyotaki. 2010. Financial intermediation and credit policy in business cycle analysis. In Handbook of Monetary Economics, 547-599. Elsevier Ltd.

Gorton, G. 2017. The History and Economics of Safe Assets. Annual Review of Economics 9:547-586.

Gorton, G., and G. Ordonez. 2014. Collateral Crises. American Economic Review 104:343-378.

Gorton, G., and G. Pennacchi. 1990. Financial Intermediaries and Liquidity Creation. Journal of Finance 45:49-71. 
Greenwood, R., S. G. Hanson, and J. C. Stein. 2016. The Federal Reserve's Balance Sheet as a Financial-Stability Tool. Prepared for the Federal Reserve Bank of Kansas City's Economic Policy Symposium in Jackson Hole 2016.

Hardy, D. C. 2020. ECB Debt Certificates: the European counterpart to US T-bills. University of Oxford Discussion Paper 913.

He, Z., and Z. Song. 2020. Agency MBS as Safe Assets.

International Monetary Fund. 2012. The Quest for Lasting Stability. Global Financial Stability Report 1-172.

Kacperczyk, M., C. Perignon, and G. Vuillemey. 2018. The Private Production of Safe Assets. CEPR Discussion Papers 12086.

Koijen, R. S. J., F. Koulischer, B. Nguyen, and M. Yogo. 2020. Inspecting the Mechanism of Quantitative Easing in the Euro Area. Journal of Financial Economics (forthcoming).

Krishnamurthy, A., and A. Vissing-Jorgensen. 2012. The Aggregate Demand for Treasury Debt. Journal of Political Economy 120:233-267.

- 2015. The impact of Treasury supply on financial sector lending and stability. Journal of Financial Economics 118:571-600.

Modigliani, Franco; Sutch, R. 1966. Innovations in Interest Rate Policy. American Economic Review 56:178-197.

Moreira, A., and A. Savov. 2017. The Macroeconomics of Shadow Banking. Journal of Finance 72:2381-2432. 
Nagel, S. 2016. The Liquidity Premium of Near-Money Assets. Quarterly Journal of Economics 131:1927-1971.

Ranaldo, A., P. Schaffner, and M. Vasios. 2020. Regulatory Effects on Short-Term Interest Rates. Journal of Financial Economics (forthcoming).

Reis, R. 2017. QE in the future: The central bank's balance sheet in a fiscal crisis. IMF Economic Review 65:71-112.

Stein, J. C. 2012. Monetary Policy as Financial Stability Regulation. Quarterly Journal of Economics 127:57-95.

Sunderam, A. 2015. Money Creation and the Shadow Banking System. Review of Financial Studies 28:939-977.

Vayanos, D., and J.-L. Vila. 2021. A Preferred-Habitat Model of the Term Structure of Interest Rates. Econometrica 89.

Wallace, N. 1981. A Modigliani-Miller Theorem for Open-Market Operations. American Economic Review 71:267-274.

Woodford, M. 2012. Methods of Policy Accommodation at the Interest-Rate Lower Bound. Proceedings - Economic Policy Symposium - Jackson Hole 185-288.

Zou, J. 2019. Information Acquisition and Liquidity Traps in Over-the-Counter Markets. 


\section{A Appendix}

\section{A.1 Balance sheet framework}

\section{A.1.1 Derivation of results in Table 2}

Overall, the sectoral holdings of safe and quasi-safe asset holdings of the banking and non-bank sector change as follows (recall that $\Delta R=\Delta G_{C B}$ ):

$$
\begin{aligned}
\Delta S A_{B A} & =(1-\rho \gamma) \Delta G_{C B} \\
\Delta S A_{B A}^{\text {Quasi }} & =-(1-\rho) \gamma \Delta G_{C B} \\
\Delta S A_{N B} & =-\rho(1-\gamma) \Delta G_{C B} \\
\Delta S A_{N B}^{\text {Quasi }} & =\rho(1-\gamma) \Delta G_{C B},
\end{aligned}
$$

which leads to a total change in safe and quasi-safe asset supply of:

$$
\begin{aligned}
\Delta S A & =\Delta S A_{B A}+\Delta S A_{N B} \\
& =(1-\rho \gamma) \Delta G_{C B}-\rho(1-\gamma) \Delta G_{C B} \\
& =(1-\rho) \Delta G_{C B} \\
\Delta S A^{\text {Quasi }} & =\Delta S A_{B A}^{\text {Quasi }}+\Delta S A_{N B}^{\text {Quasi }} \\
& =-(1-\rho) \gamma \Delta G_{C B}+\rho(1-\gamma) \Delta G_{C B} \\
& =(\rho-\gamma) \Delta G_{C B},
\end{aligned}
$$

where $\rho$ is the fraction of safe government bonds and $\gamma$ the fraction of government bonds purchased from the banking sector. 


\section{A.1.2 Boundary cases for $\rho$ and $\gamma$}

It is useful to discuss several boundary cases for $\rho$ and $\gamma$.

$\underline{\rho=\gamma=1:}$ The central bank purchases only safe assets and only from banks, meaning only banks are willing to sell these assets. In this case, (1) the total amount of safe and quasi-safe assets remains unchanged. QE is a swap of two forms of safe assets (government bonds vs. reserves). Since this swap takes place within the banking sector, (2) also the sectoral holdings of safe assets do not change. Nevertheless, (3) the composition of safe assets changes because government bonds are universally accessible while reserves are not. Universally accessible safe assets are substitute one for one with non-universally accessible safe assets.

$\underline{\rho=1 \& \gamma=0:}$ : The central bank purchases only safe assets and only from nonbanks, meaning only non-banks are willing to sell these assets. In this case, (1) the total amount of safe assets remains unchanged. However, contrary to the first case, the amount of quasi-safe assets increases exactly by the amount of the government bond purchases. Additionally, (2) the sectoral holdings of safe and quasi-safe assets change. The increase in safe asset holdings of banks is offset by a loss in safe asset holdings of non-banks. Hence, there is a transfer of safe assets from banks to non-banks due to the market segmentation in the market for reserves. Instead of being compensated with safe assets, non-banks receive bank deposits (quasi-safe assets) when selling their safe government bonds. Finally, (3) universally accessible safe assets are substitute one for one with non-universally accessible safe assets.

$\underline{\rho=0 \& \gamma=1:}$ : The central bank purchases only quasi-safe assets and only from banks. In this casse, (1) the total amount of safe assets increases and the the amount of quasi-safe assets decreases by the same amount. Since these transaction 
take place on the balance sheet of the banking sector, (2) the (quasi-)safe asset holdings of non-banks remain unchanged. (3) The amount of universally accessible safe assets remains unchanged because the central bank purchases only quasisafe assets. Simultaneously, the amount of non-universally accessible safe assets increases because the central bank pays its purchases with newly creates reserves.

$\underline{\rho=0 \& \gamma=0:}$ : The central bank purchases only quasi-safe assets and only from non-banks. In this case, (1) the total amount of safe assets increases and the amount of quasi-safe assets remains unchanged. The former is due to the fact that banks receive safe reserves because they act as intermediary. Hence, (2) the safe asset holdings of the banking sector increase. The latter is due to the fact that non-banks are compensated with bank deposits. They swap two forms of quasi-safe assets such that their (quasi-)safe asset holdings remain unchanged. (3) The amount of universally accessible safe assets remains unchanged because the central bank purchases only quasi-safe assets. Simultaneously, the amount of non-universally accessible safe assets increases because the central bank pays its purchases with newly creates reserves.

\section{A.2 Balance sheet framework extension: positive net is- suance of new government bonds}

The net issuance of government bonds is an important driver of changes in total and sectoral holdings of government bonds. Against this background, we extend our framework. We assume that an exogenous treasury can change the net debt level by purchasing or selling government bonds. ${ }^{18}$ Contrary to central bank purchases,

\footnotetext{
${ }^{18}$ Note, that selling (purchasing) government bonds corresponds to the situation in which the amount of newly issued government bonds exceeds (is smaller than) the amount of maturing ones,
} 
these operations change the amount of outstanding government bonds, i.e., $\Delta G \neq 0$. Since governments usually increase their net debt levels, we consider the case in which the treasury sells bonds, i.e., $\Delta G>0$. We assume it sells a fraction $\kappa$ to the banking and $(1-\kappa)$ to the non-bank sector. Additionally, we introduce the parameters $\left[\rho_{1}, \rho_{2}\right]$ to distinguish between safe and quasi-safe government bonds; $\rho_{1}$ represent the amount of safe assets purchased by the central bank as a share of total purchases and $\rho_{2}$ represents the amount of safe assets issued by the treasury as a share of total net issuance.

Table 6 presents the change in total and sectoral holdings of (quasi-)safe assets, if we allow for changes in government debt levels. Derivations can be found in the Appendix. Since the banking sector acts as an intermediary for non-banks, it receives additional reserves whenever banks or non-banks sell government bonds to the central bank. Hence, reserve holdings increase by $\Delta G_{C B}$. Similarly, the banking sector spends reserves whenever banks or non-banks purchase newly issued government bonds. Hence, the reserve holdings decrease by $\Delta G$. To arrive at the total change in safe asset holdings of the banking sector, we still need to take into account that banks sell safe government bonds to the central bank. This reduces their safe asset holdings by $\rho_{1} \gamma$. Additionally, they purchase safe newly issued government bonds. This increases their safe asset holdings by $\rho_{2} \kappa \Delta G$. Taken together, the total change in safe asset holdings of the banking sector amounts to $\left(1-\rho_{1} \gamma\right) \Delta G_{C B}-\left(1-\rho_{2} \kappa\right) \Delta G$.

The banking sector reduces its quasi-safe asset holdings by $\left(1-\rho_{1}\right) \gamma \Delta G_{C B}$ because it sells quasi-safe government bonds to the central bank. Simultaneously, it increases its quasi-safe asset holdings by $\left(1-\rho_{2}\right) \kappa \Delta G$ because it purchases such that the net indebtedness of the government increases (decreases). 
quasi-safe government bonds from the government.

Table 6: Change in total and sectoral holdings of (quasi-)safe assets (extension)

Table 6 presents the changes in total and sectoral holdings of safe and quasi-safe assets.

\begin{tabular}{lcc} 
& \multicolumn{1}{c}{ Safe assets } & \multicolumn{1}{c}{ Quasi-safe assets } \\
\hline Banking sector & $\left(1-\rho_{1} \gamma\right) \Delta G_{C B}-\left(1-\rho_{2} \kappa\right) \Delta G$ & $-\left(1-\rho_{1}\right) \gamma \Delta G_{C B}+\left(1-\rho_{2}\right) \kappa \Delta G$ \\
Non-bank sector & $-\rho_{1}(1-\gamma) \Delta G_{C B}+\rho_{2}(1-\kappa) \Delta G$ & $\rho_{1}(1-\gamma) \Delta G_{C B}-\rho_{2}(1-\kappa) \Delta G$ \\
\hline Total & $\left(1-\rho_{1}\right) \Delta G_{C B}-\left(1-\rho_{2}\right) \Delta G$ & $\left(\rho_{1}-\gamma\right) \Delta G_{C B}-\left(\rho_{2}-\kappa\right) \Delta G$
\end{tabular}

The non-bank sector reduces its holdings of safe government bonds by $\rho_{1}(1-$ $\gamma) \Delta G_{C B}$ because it sells these bonds to the central bank. Simultaneously, it increases its holdings of safe government bonds by $\rho_{2}(1-\kappa) \Delta G$ because it purchases these bonds from the government. Additionally, the non-bank sector increases its quasi-safe asset holdings by $\rho_{1}(1-\gamma) \Delta G_{C B}$ because it receives bank deposits for selling safe government bonds to the central bank. And it decreases its quasi-safe asset holdings by $\rho_{2}(1-\kappa) \Delta G$ because it uses its bank deposits to purchase safe government bonds from the government.

The extent to which total and sectoral holdings of (quasi-)safe assets change depends on the parameters $\rho_{1}, \rho_{2}, \gamma$, and $\kappa$. Note that only $\rho_{1}$ can be determined by the central bank. All other parameters are outside the control of monetary policy and are either determined by the government $\left(\rho_{2}\right)$ or by market participants $(\gamma$ and $\kappa)$. The bottom line of Table 6 shows that the central bank and the government can together control the total amount of safe assets. However, they cannot directly impact the cross-sectional distribution because this (also) depends on $\gamma$ and $\kappa$, i.e., on the preference of banks and non-banks to hold government bonds. It seems likely that $\gamma$ and $\kappa$ are not independent because (non-)banks can achieve their 
preferred level of safe asset holdings by adjusting the amount of government bonds they sell to the central bank $(\gamma)$ and/or the amount they purchase in primary auctions $(\kappa)$.

Against this background, we derive a measure for the preference to hold safe government bonds as a function of $\gamma$ and $\kappa$, which we can later bring to the data. To this end, we define define $\gamma=\gamma_{\text {Bank }}$ and $(1-\gamma)=\gamma_{\text {Non-bank }}=\gamma_{I C P F}+\gamma_{O F I}+$ $\gamma_{H H}+\gamma_{\text {Other }}+\gamma_{\text {Foreign. }}$. We do the same for $\kappa$. Using SHSSdata, we are able to measure the change in safe government bond holdings of our sectors $\Delta G_{\text {safe }}^{s}$, where $s \in\{$ Bank, ICPF, OFI, HH, Other, Foreign $\}$. Against this background, we use

$$
\frac{\Delta G_{\text {safe }}^{s}}{G_{\text {safe }}^{s}}=-\frac{\left(\rho_{1} \gamma^{s} \Delta G_{C B}+\rho_{2} \kappa^{s} \Delta G\right)}{G_{\text {safe }}^{s}}
$$

as a measure for the cross-sectional variation in the preference to hold safe government bonds. We can do this because the only driver of cross-sectional variation in this measure is variation in $\gamma$ and $\kappa$.

Finally, we can use the results presented in Table 6 to derive conditions for the neutrality of QE when allowing the total amount of outstanding government bonds $G$ to change. As in Proposition 1, we can derive these conditions for (1) the total amount, (2) the sectoral holdings, and (3) the composition of safe assets.

\section{Proposition 2 (Safe asset neutrality of QE)}

(i) QE is neutral to the total amount of safe assets if

- $\rho_{1}=\rho_{2}=1$, i.e., if the central bank purchases only safe government bonds and only safe government bonds are issued

- $\rho_{1} \Delta G_{C B}=\rho_{2} \Delta G$, i.e., the amount of safe government bonds purchased 
by the central bank equals the amount of newly issued safe government bonds

(ii) QE is neutral to the sectoral holdings of safe assets if

- $\rho_{1}=\rho_{2}=\gamma=\kappa=1$, i.e., if the central bank purchases only safe government bonds and only from banks; and if only safe government bonds are issued and only to banks

- $\Delta G_{C B}=\Delta G \& \rho_{1}=\rho_{2} \& \mathcal{G} \gamma=\kappa$, i.e., the amount of government bonds purchased by the central bank equals the amount of newly issued government bonds, the share of safe government bonds purchased by the central bank equals the share of safe government bonds in primary auctions, and the share of bonds purchased from banks equals the share issued to banks

(iii) QE is never neutral to the composition of safe assets, i.e., to the share of universally accessible and non-accessible safe asset.

\section{A.3 Data characteristics}

The SHSS data vintage used for our sample refers to June 2020 and data is collected on a quarterly basis by euro-area custodians. Sectors in the SHSS database are defined according to the ESA 2010 classification. Securities held exclusively by non-euro area sectors that are not held via a euro area custodians are not available in SHSS and, thereafter, neither their amount outstanding. In addition, securities which have not been redeemed yet, but have a negative residual maturity can still be reported in the investors holdings portfolio. Thus we do not include securities 
with negative residual maturity according to CSDB. We define government bonds as securities issued by ESA 2010 sectors S_13, S_1311, S_1312, S_1313 and S_1314 (general, central and local government and social security), and agency bonds (i.e. corporate bonds backed by the government) and supras held under PSPP. The classifications of the CSDB debt type variable changes after 2016Q3. Up to 2016Q3, we define corporate bonds as debt types D.1, D.11, D.15, D.16, D.164, D.18, D.3 and D.32 and which are not issued by the government sector, as well as securities included in the ECB's Corporate sector purchase program. Covered bonds and asset-back securities correspond to debt types D.21, D.23 and D.233 which are not issued by the government sector, as well as to securities included in the ECB's asset-backed securities purchase program and covered bond purchase program 3. After 2016Q3, we still follow the securities classification according to the inclusion into the corresponding ECB's purchase programs, but we define corporate bonds as debt types D.1, D.11, D.14, D.141, D.15, D.16, D.18, D. 181, D.1811, D.1812, D.1813, D.1819, D.182, D.1821 and D.1822 and which are not issued by the government sector; and covered bonds and asset-back securities correspond to debt types D.13, D.131 and D.139 and not issued by the government sector. 